\title{
Slave Prices, the African Slave Trade, and Productivity in Eighteenth-Century South Carolina: A Reply
}

\author{
Peter C. Mancall, Joshua L. Rosenbloom, and Thomas Weiss
}

The comment by David Eltis, Frank Lewis, and David Richardson brings to the fore issues about productivity growth in slave-based economies, and about broader interpretations of those societies and their successor economies. Their assessment confirms that prices derived from probate inventories behaved like those derived from market transactions, suggesting that rich data available in probate inventories can be brought to bear on important issues in colonial economic history. We disagree, however, with their finding that slave productivity in the Lower South grew much more rapidly than we estimated.

They maintain that our estimates of productivity growth are biased downward because the export price series we used to deflate the nominal slave prices rises too rapidly for two reasons. ${ }^{1}$ First, they argue that the rice price we used for the period 1722 1731 is conceptually different from the price we used for the period after 1731 . Second, they contend that Philadelphia rice prices, which were higher and rose more slowly than Charleston prices, would be a better measure of the prices received by rice producers. They also exaggerate the differences between their estimates and ours when they contend that "The lack of productivity growth is especially puzzling given our estimate that during the period 1722 to 1775 slave prices in South Carolina were increasing somewhat faster than in the Caribbean."2

Our finding of "the lack of productivity growth" to which they refer is for the entire period 1722 to 1800 , not 1722 to 1775 , a period when slave prices were rising rapidly. Their focus on the period down to the end of the century obscures an important point, namely that we also find slave productivity growth in the period before 1775 . They alluded to this in a footnote, but it needs greater stress. We estimated that real slave prices rose between 1722-1724 and 1770-1774 at an annual rate of 0.8 percent, well above the 0.4 rate they report for the Caribbean. Although our estimated increase is well below the 1.65 percent annual rate of growth that they estimate for the Lower

The Journal of Economic History, Vol. 66, No. 4 (December 2006). (C) The Economic History Association. All rights reserved. ISSN 0022-0507.

Peter C. Mancall is Professor, Department of History, University of Southern California; Joshua L. Rosenbloom is Professor, Department of Economics, University of Kansas and Research Associate, National Bureau of Economic Research; Thomas Weiss is Professor emeritus, University of Kansas and Research Associate, National Bureau of Economic Research.

This research is funded in part by the National Science Foundation (SBR 9808516). We thank Frank Lewis for providing us with their data files.

${ }^{1}$ They, and we, calculated the "real" price of slaves - the nominal slave price deflated by the price of the slaves' output - to estimate the change in productivity. For the Caribbean they used the price of sugar; for the Lower South we used South Carolina export prices. We also measured labor productivity in the Lower South in other ways and in greater detail. Mancall, Rosenbloom, and Weiss, "Agricultural Labor Productivity," pp. 390-424.

${ }^{2}$ Because of space limitations our response focuses on the central issue of the appropriate output price with which to deflate slave prices. We do not address their TFP calculations, which rest largely on the estimates of the real price of slaves. 
TABLE 1

COMPARISON OF SLAVE LABOR PRODUCTIVITY INDEXES, 1722-1724 TO $1805-1809$

\begin{tabular}{|c|c|c|c|c|}
\hline & \multicolumn{3}{|c|}{ Mancall, Rosenbloom, Weiss Indexes } & \multirow{2}{*}{$\begin{array}{c}\text { Eltis, Lewis, } \\
\text { Richardson Index } \\
\text { Deflated by } \\
\text { Export Prices }\end{array}$} \\
\hline & $\begin{array}{l}\text { Original } \\
\text { Series }\end{array}$ & $\begin{array}{c}\text { First } \\
\text { Adjusted } \\
\text { Series }\end{array}$ & $\begin{array}{c}\text { Second } \\
\text { Adjusted } \\
\text { Series }\end{array}$ & \\
\hline $1722-1724$ & 100 & 100 & 100.0 & 100 \\
\hline $1725-1729$ & 92 & 92 & 94.9 & \\
\hline $1730-1734$ & 96 & 100 & 104.9 & \\
\hline $1735-1739$ & 65 & 69 & 72.4 & \\
\hline $1740-1744$ & 96 & 102 & 106.4 & \\
\hline $1745-1749$ & 107 & 115 & 130.5 & \\
\hline $1750-1754$ & 104 & 111 & 114.4 & \\
\hline $1755-1759$ & 100 & 107 & 110.5 & \\
\hline $1760-1764$ & 146 & 156 & 161.8 & \\
\hline $1765-1769$ & 137 & 146 & 150.9 & \\
\hline $1770-1774$ & 145 & 155 & 157.5 & 223 \\
\hline $1775-1779$ & 170 & 182 & 185.3 & \\
\hline \multicolumn{5}{|l|}{$1780-1784$} \\
\hline $1785-1789$ & 92 & 99 & 102.5 & \\
\hline $1790-1794$ & 95 & 102 & 105.8 & \\
\hline 1795-1799 & 107 & 114 & 118.4 & \\
\hline 1800-1804 & 106 & 114 & 118.2 & \\
\hline 1805-1809 & 140 & 150 & 155.8 & \\
\hline $1802-1806$ & 122 & 131 & 135.8 & 169 \\
\hline \multicolumn{5}{|c|}{ Average Annual Rates of Change } \\
\hline $1722-1724$ to $1770-1774$ & 0.76 & 0.89 & 0.93 & 1.65 \\
\hline $1770-1774$ to $1802-1806$ & -0.52 & -0.52 & -0.46 & -0.86 \\
\hline $1722-1724$ to $1802-1806$ & 0.25 & 0.33 & 0.38 & 0.65 \\
\hline
\end{tabular}

Notes and Sources:

Our Original Index series is from Mancall, Rosenbloom, and Weiss, "Slave Prices ," table 3. That table shows an index of 157.2 for $1770-1774$, but that figure was a typographical error. The correct index value should be 144.6. We have added figures for 1802-1806 for comparison with Eltis et al.

The fluctuations in the indexes, such as the large decline between 1730-1734 and 1735-1739, are discussed in the earlier article "Slave Prices."

The First Adjusted series was calculated by assuming that the change in definition from farm-gate prices in the years 1722-1731 to wholesale prices thereafter produced a one-time jump of 7 percent, the upper bound of the difference specified by Peter Coclanis, Shadow of a Dream, p. 106.

The Second Adjusted series revises the first adjusted series by using more recent currency exchange rates than those that were available when we made our original estimates. The older figures were from McCusker, Money and Exchange, pp. 222-25. The new rates are from Carter et al., Historical Statistics, vol. 5, Series Eg 323

The Eltis et al. index is from Eltis et al., "Slave Prices," table 2.

South (see Table 1), it is not so low that we can be accused of harkening "back to a traditional view of slavery as inefficient and nonproductive."

Our estimate of slave productivity growth between mid-century and the Revolution fits the anecdotal evidence cited by Eltis et al. that "a good working hand on a rice 


\section{Mancall, Rosenbloom, and Weiss}

plantation [prior to 1748] produced about 2,250 pounds of clean rice per year, the figure for an average hand had apparently grown to about 3,000 to 3,600 pounds yearly during the second half of the eighteenth century, with good hands capable of even more." ${ }^{\prime 3}$ That anecdote implies an increase in productivity of between 33 and 60 percent sometime after 1748 . Our estimate, that slave productivity increased by 59 percent between $1745-1749$ and $1775-1779$, is very much in line with that implied percentage increases. ${ }^{4}$ Indeed our estimates are generous in light of that anecdotal evidence.

We believe that Charleston prices were the appropriate ones to use because Charleston was the major market for the export of rice, and rice prices were readily available to rice planters. The question was how to extend the series to dates before the first observation reported by Arthur H. Cole. ${ }^{5}$ We did so by linking the Charleston wholesale prices to the price series reported by Peter Coclanis in his widely praised study of the lowcountry. ${ }^{6}$ We recognize that the prices for 1722 to 1731 might be best regarded as farm-gate prices and might have differed from the wholesale prices used for the period from 1732 onward, but because the series do not overlap there is no way to assess the effect of the change in concept between them, and our extrapolation includes the effect of this one-time adjustment. ${ }^{7}$ From 1731 to 1732 rice prices increased by 13 percent. Coclanis thought that farm prices were only "two or three shillings currency per hundredweight" lower than wholesale prices, which means that the 1731 farm price may have been only 5 to 7 percent below the wholesale price. ${ }^{8}$ If this is correct, about half the price change from 1731 to 1732 reflects differences in concept between the two series. Although this is not negligible, it is certainly far lower than the bias of 30 percent suggested by Eltis, et al.

The "First Adjusted" slave price series in Table 1 shows slave productivity estimates using a rice price series adjusted for the possible effect of the change from farmgate prices to wholesale prices that occurred in 1731-1732. Real slave prices increase more than we originally suggested, but still far less than found by Eltis et al.: the index value for 1770-1774 is 155 rather than our original estimate of 145 and the 223 figure found by Eltis et al. For 1802-1806 the index is 131, which is above our original estimate of 122, but well below the 169 figure of Eltis et al. The adjustment for this possible bias narrows the gap between our estimates and theirs, but the crucial differences still remain and rest on the second part of the critique offered by Eltis et al.: should we use Charleston prices or Philadelphia prices to deflate the nominal slave prices?

We contend that the Charleston price series is the preferred one for calculating the real price of slaves in the Lower South because it was the one monitored by Southern slave owners. Eltis et al. think the Philadelphia series would be a better gauge because

\footnotetext{
${ }^{3}$ The quote is from Coclanis, Shadow, p. 97. The figure of 3,000 to 3,600 pounds came from an entry in George Washington's diary for May 1791, but the observation is not directly linked to any actual production statistics, or even any specific crop year. Fitzpatrick, ed., Diaries of George Washington, vol. 4: pp. 171-72.

${ }^{4} \mathrm{We}$ found an even greater increase of 78 percent between $1740-1744$ and $1775-1779$.

${ }^{5}$ Wholesale Commodity Prices.

${ }^{6}$ The farm-gate prices are from Peter Coclanis, Shadow, p. 106.

${ }^{7}$ Coclanis seemed to think that his farm-gate prices could be linked directly to Cole's prices, and in the latest edition of Historical Statistics the Cole price series is combined with Coclanis's prices in one continuous series without any adjustment for differences in definition. Carter et al., eds., ibid., Series Eg299.

${ }^{8}$ Eltis, Lewis, and Richardson were aware of Coclanis's point about relative prices, citing his opinion that the difference between the two prices was 5 to 10 percent. Eltis et al., "Reassessment," fn. 18.
} 
they think there are biases in the Charleston prices. Specifically, they argue that Charleston prices were influenced by changes in the quality of rice, whereas Philadelphia's were not. If the Charleston wholesale price reflected only the price of rice that was domestically consumed, as they seem to imply, then the local price would tend to fall when strong export growth reduced the share of high quality rice in the local market. But if, as seems more likely and more widely accepted, the Charleston price reflected both the local and the export market, then it is not clear how, if at all, the changing composition would affect the price. ${ }^{9}$

Even if they are right about the changes in the quality of rice exports, it is not clear how this would contribute to a more rapid long-term growth of the Charleston rice price, either absolutely or relative to the Philadelphia price. ${ }^{10}$ Shifts in quality might have caused some fluctuations in the Charleston price, as their argument suggests, but an alteration in the trend would require a long-term change in the quality composition of the rice supply. Eltis et al. have not indicated whether there was a long-term change in the composition, or whether it was an increase or decrease in the lower quality share. Without a clearer specification of the wholesale market for rice in Charleston and of the timing of growth of export demand, we do not see how anything definitive can be said about how changes in the quality composition caused Charleston rice prices to rise more rapidly than Philadelphia prices over the long term. What we do know, of course, is that market forces did push up the price of both high quality and low quality rice in Charleston because they were substitute goods, and planters would have been well aware of these changes because they were reported regularly in the South Carolina Gazette after 1732.

Why then should the Philadelphia price be a better gauge of the price that planters in South Carolina would have used to judge how much a slave worker was worth? The only defense offered by Eltis et al. is that Philadelphia prices moved much more closely with rice prices in England and Holland. That begs the question. Why should prices in far more distant markets be a better indication of what South Carolina producers observed than the prices in their own backyard? Why should the behavior of prices in three locations that consumed rice be preferred to prices observed in the markets supplied by southern rice planters? Charleston prices would have been heavily influenced by foreign markets for rice, markets in which Charleston, not Philadelphia or London, was the major supplier. ${ }^{11}$

There seems little doubt that rice planters paid attention to the Charleston prices. ${ }^{12}$ In his Description of South Carolina, Govern James Glen reported prices that accorded closely with those reported by Arthur H. Cole. According to Glen, "Rice last year bore a good price, being at a medium about forty-five shillings of our currency per hundred weight; and all this year it hath been fifty-five shillings and three

\footnotetext{
${ }^{9}$ The price would have risen when there was strong growth of demand, but not necessarily because of the changing quality composition.

${ }^{10}$ The more rapid growth of Charleston prices also means that they were converging towards Philadelphia's, something not seen easily in the index numbers depicted in their Figure 2. One might imagine that improvements in transportation and distribution could account for this.

${ }^{11}$ In the period 1768-1772, rice exports from the Lower South, most of which left from Charleston, amounted to 98 percent of all rice exports. Less than 2 percent was exported via the Middle Colonies. Shepherd and Walton, Shipping, Appendix 4.

${ }^{12}$ Almost all colonial historians agree on the primacy of the Charleston prices, which were reported regularly in the South Carolina Gazette after 1732. See Coclanis, "Rice Prices"; Egnal, New World Economies, p. 103, figure 1; and Nash, "South Carolina." McCusker and Menard show both Charleston and Philadelphia prices, the latter because they extended back to 1720 , Economy, p. 177, figure 8.1.
} 
Pounds." ${ }^{13}$ It is not entirely clear to which year he is referring; his description was published in 1751 , but he was writing it in 1748 or early $1749 .{ }^{14}$ The average monthly prices shown by Cole were 49 shillings in 1748, 60 in 1749, 63 in 1750 and 46 shillings in $1751 .{ }^{15}$

One can also see in Table 1 that there is a noticeable difference between our estimate and that of Eltis et al. as regards the behavior of real slave prices between the Revolution and the turn of the century. They found that the real slave price declined after the war, but stressed that "by the end of the period, the "real' price of slaves was more than 70 percent above the 1722 level." While true, that was 54 percentage points below the level found for the years just prior to the Revolution. Productivity by their estimate was declining at nearly 0.9 percent per year for 32 years. Our estimates show a more modest decline of around 0.5 percent per year. This is still substantial, but it is not a comment on the inefficiency or inflexibility of the slave system. It is a reflection of the fact that the export market was languishing. The disruptions of the Revolutionary War and the period of Confederation left their mark: exports increased, but not as rapidly as the slave workforce. It was only with the burgeoning of the cotton market after 1793 that production and exports began to recover. ${ }^{16}$

These large productivity declines, and the wide range of the estimates for this relatively short period, highlight the need for further research for the two decades following the peace of 1783. Although we differ from Eltis et al. about how to estimate certain aspects of the postwar economy, their findings and ours each suggest the persistence of the "statistical dark age" to use the apt phrase of Paul David. ${ }^{17}$ Only further research on the economy of eighteenth-century mainland North America will reveal the sources that provide the clearest insights into the nature and rate of productivity growth during this crucial era.

\footnotetext{
13 "A Description of South Carolina" reprinted in Milling, ed., Colonial South Carolina, p. 16.

${ }^{14}$ Coclanis argued that Glen wrote in 1748; see Shadow, p. 97.

${ }^{15}$ Prices are from Carter et al., eds., Historical Statistics 5: 688 (Series Eg299). Among other examples is an untitled article that used Charleston prices to project income for a proposed investment venture in South Carolina. Gentleman's Magazine 25 (May 1755): pp. 201-03 and (June 1755): 256-59, cited in Merrens, ed., South Carolina Scene, pp. 160-63.

${ }^{16}$ Even with the fillip provided by cotton, we estimate that the real volume of exports per slave worker in 1800 was roughly one-half that of 1770. Mancall, Rosenbloom, and Weiss, "Agricultural Labor Productivity," table 2, p. 406.

${ }^{17}$ David, "New Light," pp. 294-306.
}

\section{REFERENCES}

Carter, Susan, Scott Sigmund Gartner, Michael R. Haines, Alan L. Olmstead, Richard Sutch, and Gavin Wright, eds., Historical Statistics of the United States: Earliest Times to the Present. New York: Cambridge University Press, 2006.

Coclanis, Peter A. "Rice Prices in the 1720s and the Evolution of the South Carolina Economy." The Journal of Southern History 48 (1982): 531-44.

Coclanis, Peter. The Shadow of a Dream. New York: Oxford University Press, 1989.

Cole, Arthur Harrison. Wholesale Commodity Prices in the United States, 1700-1861. Cambridge, MA: Harvard University Press, 1938.

David, Paul. "New Light on a Statistical Dark Age: U.S. Real Product Growth Before 1840." The American Economic Review 57 (May 1967): 294-306.

Egnal, Marc. New World Economies. New York: Oxford University Press, 1998.

Eltis, David, Frank D. Lewis, and David Richardson. "Slave Prices, the African Slave 
Trade, and Productivity in the Caribbean, 1674-1807." The Economic History Review 58 (November 2005): 680-83.

Eltis, David, Frank D. Lewis, and David Richardson. "Slave Prices, the African Slave Trade, and Productivity in Eighteenth Century South Carolina: A Reassessment." This JOURNAL 66, no. 4 (2006): 1054-65.

Fitzpatrick, J. C. ed. Diaries of George Washington, 1748-1799. 4 vols. Boston: Houghton Mifflin, 1925.

Glen, James. "A Description of South Carolina" [London: for R\&J Dodsley, 1761] reprinted in Colonial South Carolina: Two Contemporary Descriptions, edited by Chapman J. Milling, 3-104. Columbia: University of South Carolina Press, 1951.

Mancall, Peter C., Joshua Rosenbloom, and Thomas Weiss. "Slave Prices and the South Carolina Economy, 1722-1809" This JouRnaL 61, no. 3 (2001): 616-39.

"Agricultural Labor Productivity in the Lower South, 1720-1800." Explorations in Economic History 39 (2002): 390-424.

McCusker, John. "How Much is That in Real Money? A Historical Price Index for Use as a Deflator of Money Values in the Economy of the United States." Proceedings of the American Antiquarian Society 101, part 2 (October 1991): 297373.

. Money and Exchange in Europe and America, 1600-1775: A Handbook. Chapel Hill: North Carolina University Press, 1978.

Merrens, H. Roy, ed. The South Carolina Scene: Contemporary Views, 1697-1774 Columbia: University of South Carolina Press, 1997.

McCusker, John J., and Russell R. Menard. The Economy of British America: 16071789. Chapel Hill: University of North Carolina Press, 1985.

Nash, R. C. "South Carolina and the Atlantic Economy in the Late Seventeenth and Eighteenth Centuries." Economic History Review 45 (November 1992): 677-702.

Shepherd, James, and Walton, Gary. Shipping, Maritime Trade and the Economic Development of Colonial North America. Cambridge: Cambridge University Press, 1972. 